\title{
Yhteisöllinen luovuus ja ekspansiivinen oppiminen harjoittelukoulun Muutoslaboratoriossa
}

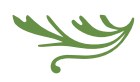

Ekspansiivisen oppimisen taustalla vaikuttaa yhteisöllinen luovan käsitteenmuodostuksen prosessi. Se auttaa selittämään, miten yksilöiden luovista teoista voi vuorovaikutuksessa kehittyä koko toimintajärjestelmää uudistavia jaettuja käsitteitä ja työkäytäntöjä. Miten tämä toteutui hankkeessa, jossa opettajayhteisö ideoi ja kehitti pedagogisen toiminnan tiimityö- ja johtamismallin? Yhteisöllistä luovuutta ja sen suhdetta yhteisölliseen oppimiseen on tutkittu vain vähän asiantuntijaorganisaatioissa.

$\mathbf{y}$ 'LUOVUUS' MÄÄRITELLÄÄN psykologisissa tutkimuksissa perinteisesti yksilön kyvyksi tuottaa uusia ja käyttökelpoisia ideoita, näkemyksiä ja ratkaisuja (ks. esim. Amabile 1996; Woodman ym. 1993; Sternberg \& Lubart 1999). Yksilölähtöistä luovuuskäsitystä on sittemmin pyritty laajentamaan tutkimalla luovuutta moniulotteisena, yhteisöllisenä ja yksilöiden välisessä vuorovaikutuksessa ilmenevänä ilmiönä (Csikszentmihalyi 1996; John-Steiner 2000; Greeno 2006; Sawyer \& deZutter 2009; Glaveanu 2011; Littleton ym. 2012; Sannino \& Ellis 2013; Runco \& Beghetto 2019).

Luovien prosessien tarkastelussa on lisäksi huomioitava niihin keskeisesti vaikuttavat sosiaalinen konteksti, kulttuuri ja yhteisöt (Drazin ym. 1999; Sawyer 2004; Glaveanu 2011). Esimerkiksi työelämässä luovuus hahmotetaan usein yhteisöllisinä, uutuusarvoisia tuloksia tuottavina prosesseina ja käytäntöinä, kuten luovana ongelmanratkaisuna (Segers ym. 2018; Hakkarainen ym. 2013; Oddane 2014). Työn kehittämisen ja organisaatioiden oppimisen kannalta onkin keskeistä kannustaa työyhteisöjä luovuuteen ja paikallisesti tukea yhteistoiminnallisten, luovien työkäytäntöjen kehittelyä (Córdova ym. 2012).

Yhteisöllinen tai jaettu luovuus on monimutkainen ja monitahoinen tutkimuskohde, ja sen vuoksi sitä on vaikea märiritellä yksiselitteisesti (Glaveanu 


\section{OpetusuUnNitelmatyöss $\ddot{A}$}

OPETTAJAYHTEISÖILT $\ddot{A}$

ODOTETAAN PAIKALLISIA,

LUOVUUTTA VAATIVIA

RATKAISUJA.

2015; Amabile 1996; Littleton ym. 2012). Yhteisöllistä luovuutta ja sen suhdetta yhteisölliseen oppimiseen on tutkittu vain vähän asiantuntijaorganisaatioissa, joiden kuitenkin odotetaan lähtökohtaisesti olevan uutta luovia. Yhteisöllinen luovuus on keskeinen esimerkiksi innovatiivisuuden ja kilpailukyvyn parantamisessa (Gruys ym. 2011; Kaufman \& Sternberg 2009) sekä uusien luovien prosessien ja keksintöjen tuottamisessa (Anderson ym. 2014; Schulz ym. 2017).

Suomalaisessa koulumaailmassa yhteisöllinen luovuus on tärkeä ja ajankohtainen tutkimusaihe. Opettajayhteisöt ovat monien muutosvaatimusten kohteena, kun esimerkiksi opetussuunnitelmatyössä tulisi tehdä paikallisia, luovuutta vaativia ratkaisuja valtakunnallisten opetussuunnitelman perusteiden pohjalta.

Luovuus on potentiaalinen muutoksen, innovaatioiden ja oppimisen ajuri ja mahdollistaja (ks. myös McCharen ym. 2011). Tutkimme tässä artikkelissa yhteisöllisen luovuuden (Sannino \& Ellis 2013; Sawyer \& deZutter 2009) mekanismeja ja niiden yhteyttä oppimiseen. Lähtökohtamme on ekspansiivisen oppimisen teoria (esim. Engeström 2014; Engeström ym. 2015), joka tarkastelee työyhteisöjen yhteisöllistä oppimista toiminnan taustalla piilevien ristiriitojen ja jännitteiden tunnistamisen sekä niiden ratkaisemiseksi yhdessä kehitettävien uusien käytäntöjen kautta.

Määrittelemme yhteisöllisen luovuuden sosiaalisesti jaetuksi prosessiksi, joka rakentuu yksilöiden vuorovaikutuksessa tekemistä luovista teoista (ks. Sawyer \& deZutter 2009). Tarkastelemme luovuutta sosiomateriaalisesti välittyneenä toimintana, jota välittävät toimintaan osallistuvien keskustelu ja heidän käytettävissään olevat välineet (Vygotsky
1978; Engeström 2014; Miettinen 2013). Huomiomme kiinnittyy siten yksilöiden luovien tekojen ohella erityisesti vuorovaikutuksessa tapahtuviin luoviin prosesseihin, joissa luodaan yhteisöllisesti uusia yhteisiä käytäntöjä (Hakkarainen ym. 2012). Pidämmekin yhteisöllistä luovuutta ja oppimista sekä uusia jaettuja käytäntöjä yhteenkietoutuneina (ks. myös Sannino \& Ellis 2013), jonkin sellaisen oppimisena, jota ei vielä ole olemassa (Engeström 2014).

Tutkimuksemme aineisto kerättiin keväällä 2015 suomalaisen harjoittelukoulun alakoulussa toteutetussa kehittämishankkeessa, johon osallistui koulun opettajia ja rehtori. Hankkeen ohjanneet tutkijat, mukaan luettuna toinen tämän artikkelin kirjoittajista, hyödynsivät hankkeessa ekspansiivista oppimista soveltavaa Muutoslaboratorio-menetelmää. Tutkimuskysymyksemme ovat, 1) minkälaisia luovia tekoja Muutoslaboratoriossa ilmeni sekä 2) edistikö yhteisöllinen luova prosessi Muutoslaboratorion osallistujien ekspansiivista oppimista ja jos, niin miten.

Yhteisöllisen luovuuden ja ekspansiivisen oppimisen yhteyttä ei ole aiemmin empiirisesti tutkittu, joten kehitimme uudenlaisen analyysimenetelmän yhteisöllisten luovien prosessien tutkimiseksi. Paikansimme ensin aineistosta yksittäisten osallistujien luovia tekoja, uudenlaisen idean esitteleviä keskustelualoitteita tai rakentavia vastauksia aiempiin aloitteisiin. Sen jälkeen tunnistimme vuorovaikutusprosesseja, joiden myötä luovat teot ketjuuntuivat yhteisiksi pyrkimyksiksi käsitteellistää työtoimintaa uudella tavalla. Näitä uudenlaisia, työtoiminnan analysoinnissa esiin nousseisiin ristiriitoihin vastanneita käsitteellistyksiä kutsumme luoviksi harppauksiksi. Kehittämällämme välineellä voidaan analysoida ja käsitteellistää työyhteisöissä ilmeneviä jaettuja luovia prosesseja. Samalla se lisää ymmärrystämme ekspansiivisen oppimisen uutta luovasta luonteesta.

\section{LUOVUUS OPPIMISEEN KYTKEYTYVÄNÄ PROSESSINA}

Metodologinen ja teoreettinen lähtökohtamme on kulttuurihistoriallinen toiminnan teoria ja sen sovelluksena työelämän ja organisaatioiden kontekstiin 
VAATIMUKSET AINERAJAT

YLITTÄVÄSTÄ OPETUKSESTA JA

JAETUISTA TYÖKÄYTÄNNÖISTÄ

ASETTIVAT HAASTEEN

KOULUN OMALLE

OPETUSSUUNNITELMATYÖLLE.

kehitetty ekspansiivisen oppimisen teoria (esim. Engeström 2014; Engeström ym. 2015). Se tarkastelee työyhteisöjä paikallisina kollektiiveina, jotka pyrkivät uudistamaan käytäntöjään kehittämällä uusia käsitteitä ja toimintamalleja. Tästä näkökulmasta luovuus kytkeytyy tiiviisti yhteisölliseen oppimiseen, ja sitä pidetään keskeisenä tekijänä uusien ja merkityksellisten käsitteiden ja tulosten tuottamisessa (Engeström 2011; Sannino \& Ellis 2013). Yhteisöllistä luovuutta, kuten ekspansiivista oppimista, voidaankin pitää kontekstisidonnaisena prosessina (Glaveanu 2011; Sawyer 2004; Drazin ym. 1999), jonka osallistujat hyödyntävät toistensa tietoja ja tuottavat uutta tietoa (Segers ym. 2018; Oddane 2014) ja käytäntöjä kyseiseen kontekstiin.

Kulttuurihistorialliseen toiminnan teoriaan nojaten näemme luovuuden yhteiseen toiminnan kohteeseen suuntautuneena prosessina, johon vaikuttavat ja jota edistävät yhteisöjen ja niiden verkostojen jaetut tietokäytännöt (Hakkarainen ym. 2012). Voidakseen tuottaa uusia käsitteitä, tietokäytäntöjä ja toimintamalleja luova oppimisprosessi edellyttää toimijoiden välistä dialogia sekä yhteistoimintaa tukevia paikkoja ja välineitä (Engeström ym. 2014; Kajamaa ym. 2019; Kajamaa \& Kumpulainen 2020; Riikonen ym. 2020).

Yhteisölliselle luovuudelle tyypillisiä uusia ja odottamattomia ratkaisuja on havaittu etenkin suhteellisen rajoittamattomissa konteksteissa (Sawyer \& deZutter 2009), jotka mahdollistavat totunnaisten rajojen ylittämisen ja kokeilevat yhteistoiminnalliset prosessit (Engeström ym. 1995). Yksi tällainen on Helsingin yliopiston toiminnan teorian ja kehittävän työntutkimuksen yksikössä kehitetty Muutoslaboratorio. Se on kulttuurihistorialliseen toiminnan teoriaan ja ekspansiivisen oppimisen teoriaan perustuva osallistava työn ja organisaatioiden kehittämismenetelmä (ks. esim. Engeström ym. 1996; Kerosuo ym. 2010; Virkkunen \& Newnham 2013).

Ekspansiivinen oppiminen Muutoslaboratoriossa perustuu työyhteisön toiminnan hahmottamiseen historiallisesti kehittyneenä, systeemisenä toimintajärjestelmänä (Engeström 2014), jonka jännitteitä ja ristiriitoja tunnistetaan, analysoidaan ja ratkaistaan keskustelemalla. Paikallisia työkäytäntöjä kehittämällä pyritään kestäviin järjestelmätason muutoksiin organisaation toiminnassa (ks. esim. Engeström \& Sannino 2010; Engeström ym. 2007) sekä yhteisön rakentamisen tukemiseen (Engeström ym. 2010).

Yhteisöllinen oppimisprosessi kuvataan tyypillisesti ekspansiivisten oppimistekojen syklimäisenä etenemisenä, joka sisältää useimmiten edestakaista syklin vaiheiden välistä liikettä. Oppimistekoja ovat vallitsevien käytäntöjen kyseenalaistaminen, käytäntöjen analyysi, uuden ratkaisun mallintaminen, mallin tutkiminen ja koettelu, mallin käyttöönotto, prosessin reflektointi ja arviointi sekä uuden mallin vakiinnuttaminen. (Ks. Virkkunen \& Newnham 2013; myös Engeström 2014).

Kaikki Muutoslaboratorio-hankkeet eivät tuota luovia malleja tai ekspansiivista oppimista (Engeström ym. 2013), minkä vuoksi on tärkeää ymmärtää paremmin ekspansiivisen oppimisen taustalla vaikuttavia vuorovaikutuksellisia ja luovia prosesseja. Tutkimuskysymyksiimme vastataksemme analysoimme Muutoslaboratorioon osallistuneiden luovia tekoja sekä sitä, miten yhteisöllinen luova prosessi edisti ekspansiivista oppimista.

\section{TUTKIMUSASETELMA}

Tutkimuskohteemme on yliopiston alaisuudessa toimiva harjoittelukoulu, jonka päätehtäviä ovat perusopetus, opetusharjoittelijoiden ohjaus, tutkimus, kokeilu- ja kehittämistoiminta sekä opetuksen kehittäminen. Tutkimuksemme käynnistyessä keväällä 


\begin{tabular}{|l|l|l|l|l|l|}
\hline & Kesto & Puheenvuoroja & Uusia opettajia & Vanhoja opettajia & Rehtori \\
\hline Kokous $\mathbf{1}$ & $93 \mathrm{~min}$. & 575 & 2 & 6 & - \\
\hline Kokous 2 & $103 \mathrm{~min}$. & 564 & 1 & 7 & 1 \\
\hline Kokous 3 & $98 \mathrm{~min}$. & 590 & 1 & 6 & 1 \\
\hline Kokous 4 & $95 \mathrm{~min}$. & 592 & 2 & 4 & - \\
\hline Kokous 5 & $98 \mathrm{~min}$. & 782 & 1 & 7 & 1 \\
\hline Kokous 6 & $93 \mathrm{~min}$. & 1491 & 1 & 5 & - \\
\hline
\end{tabular}

Taulukko 1. Muutoslaboratoriokokousten kesto, puheenvuorot ja osallistujat.

2015 harjoittelukoulun alakoulussa valmisteltiin uusien opetussuunnitelman perusteiden (POPS 2014) mukaista paikallista perusopetuksen opetussuunnitelmaa. Uudet vaatimukset ainerajat ylittävästä opetuksesta ja jaetuista työkäytännöistä asettivat erityisen haasteen koulun omalle opetussuunnitelmatyölle ja tulevan opetuksen suunnittelulle. Vahvaa opettajien päätösvaltaa ja itsenäistä pedagogista asiantuntijaasemaa arvostavassa kouluyhteisössä alkoi ilmetä jännitteitä ja ristiriitoja, kun uusien vaatimusten myötä opettajien työn perinteisiä rajoja ja sääntöjä koeteltiin.

Tutkijaryhmämme ehdotti alakoulun rehtorille Muutoslaboratorio-kehittämishanketta opettajayhteisöön kohdistuviin opetussuunnitelmauudistuksen haasteisiin ja muihin muutosvaatimuksiin vastaamiseksi. Muutoslaboratorion osallistujat, kaikkiaan 14 henkilöä, olivat alakoulun opettajia ja erityisopettajia sekä rehtori. Kuhunkin kokoukseen osallistui tutkijoiden lisäksi kuudesta yhdeksään henkilöä. Osallistuminen oli vapaaehtoista, ja kaikki kuusi kokousta järjestettiin noin viikon välein koulun tiloissa.

Aineistomme käsittää kuusi videokuvattua Muutoslaboratorio-kokousta (taulukko 1). Aineisto on enimmäkseen laadukasta lukuun ottamatta ajoittaista epäselvää puhetta tai kohtia, joissa puhujaa ei voida tunnistaa. Kirjallisessa muodossa kokousaineisto käsittää 276 sivua tekstiä, 4594 puheenvuoroa.

Ryhmittelimme hankkeeseen osallistuneet opettajat analyysissä "uusiin" ja "vanhoihin" opettajiin (taulukko 1): alle vuoden kyseisessä koulussa työskennelleet merkittiin uusiksi. Jakoa perusteli näiden ryhmien erilainen panos luovaan prosessiin: "vanhat" opettajat hyödynsivät koulun vakiintuneiden rakenteiden, käytäntöjen ja haasteiden tuntemustaan, "uudet" taas korostivat kokemuksiaan aiemmista kouluistaan ja etenkin niiden hyvistä käytännöistä.

Tekstimuotoisissa aineisto-otteissa osallistujien nimet korvataan seuraavilla lyhenteillä:

vanha opettaja $(\mathrm{VO})$

uusi opettaja (UO)

rehtori (RE)

tutkija (TU)

tunnistamaton henkilö (U).

Aineistoon on merkitty lisäksi

epäselvä puhe (---)

keskeytys (\#)

päällekkäinen puhe (\#\#)

kesken jäänyt puheenvuoro ( ...)

aineisto-otteen lyhennys ([----])

fyysisen toiminnan kuvaus, esimerkiksi [piirtäminen].

Muut tunnistettavat yksityiskohdat, kuten ulkopuolisten nimet ja paikannimet, muutettiin tutkimuskohteiden anonymiteetin varmistamiseksi.

Muutoslaboratorion tuloksena, kuudennessa kokouksessa, opettajaryhmä kiteytti hankkeen aikana kehitetyt ratkaisut ja käytännöt uudenlaiseksi pedagogisen toiminnan tiimityö- ja johtamismalliksi. Se tarjosi ratkaisun moniin prosessin aikana esiin nousseisiin 


\section{LUOVA TEKO NÄYTTÄYTYI}

\section{AINEISTOSSA ESIMERKIKSI}

YHTÄKKISEN $\ddot{A}$ AIHEEN

\section{VAIHTONA TAI PUHEENVUORON \\ KESKEYTYKSEN $\ddot{\text {. }}$}

jännitteisiin ja ristiriitoihin ja edisti samalla yhteisen toiminnan muutosta. Hankkeessa siis tapahtui ekspansiivista oppimista. Tulosluvussa kuvaamme havaitsemamme keskeiset yhteisöllistä luovuutta ilmentävät prosessit, jotka liittyivät uuden toimintamallin sekä sen rakenteiden ja käytäntöjen kehittelyyn.

\section{Aineiston analyysi}

Harjoittelukoulun Muutoslaboratorio-hanke sisälsi monia poikkeamia tutkimusryhmän suunnittelemasta "käsikirjoituksesta" ja tarjosi siten mahdollisuuksia ennalta suunnittelemattomiin kokeiluihin ja luoviin ratkaisuihin hankkeen kulussa. Tutkimme, minkälaisia luovia tekoja Muutoslaboratoriossa ilmeni ja millä tavalla yhteisöllinen, vuorovaikutteinen luova prosessi edisti ekspansiivista oppimista. Aloitimme analyysin katsomalla ensin läpi koko videoaineiston. Sen jälkeen keskityimme yksittäisiin vuorovaikutusjaksoihin, joissa havaitsimme sekä yhteisöllisen luovuuden piirteitä (Sawyer \& deZutter 2009; Sannino \& Ellis 2013) että merkkejä ekspansiivisesta oppimisesta (Engeström 2014).

Puheen analyysin ohella keskityimme videokuvasta havaittavaan osallistujien kehonkieleen, kuten asentoihin, liikkeisiin, eleisiin, nyökyttelyyn ja katsekontaktin hakemiseen (ks. myös Csikszentmihalyi 1996; John-Steiner 2000; Sawyer \& deZutter 2009). Kiinnitimme huomiota myös vuorovaikutuksen sosiomateriaaliseen välittyneisyyteen ja erilaisten välineiden hyödyntämiseen osana luovaa prosessia (ks. myös Kajamaa \& Kumpulainen 2020; Riikonen ym. 2020). Analyysiyksikkömme on vuorovaikutusjakso, jonka tulkitsimme alkavan jonkun osallistujan luovasta keskustelualoitteesta ja päättyvän, kun keskustelu kyseisestä aiheesta päättyi. Erottelimme analyysissa osallistujien ja tutkijoiden osallisuuden luovaan prosessiin.

Analyysistämme muodostui kolmivaiheinen. Ensimmäisessä vaiheessa analysoimme katkelmia, joissa joku osallistujista aloitti keskustelun tekemällä luovan teon eli omaperäisen aloitteen, johon muut osallistujat vastasivat omilla luovilla teoillaan, jolloin ehdotetun keskustelunaiheen ympärille syntyi luovaa vuorovaikutusta. Tyypillisesti luova teko näyttäytyi aineistossa yhtäkkisenä aiheen vaihtona, toisen puheenvuoron keskeytyksenä, aivan uudenlaisen idean "heittona" tai toiminnan, kuten piirtämisen, aloittamisena. Kaikki aineistossa ilmenneet luovat aloitteet eivät johtaneet luovaan vuorovaikutukseen, kun niihin ei vastattu. Keskitymme tutkimustulostemme raportoimisessa sellaisiin jaksoihin, joissa luovaa vuorovaikutusta kehittyi ja jotka myös päättyivät ennalta-arvaamattomaan lopputulokseen (ks. Sawyer \& deZutter 2009).

Analyysin aikana havaitsimme pian, että luovat teot usein seurasivat toisiaan ja että niillä oli kokousten ja vuorovaikutuksen edetessä taipumus ketjuuntua ja synnyttää uudenlaisia työtoimintaa koskevia käsitteellistyksiä, joita aloimme kutsua luoviksi harppauksiksi. Ne muodostivat analyysimme toisen vaiheen. Tutkiessamme luovien harppausten vaiheittaista muodostumista ja sisältöä tunnistimme vuorovaikutuksessa erilaisia yhteisen tiedonmuodostuksen ilmentymiä, kuten katsekontaktin hakemista, nyökyttelyä, oman puheenvuoron "avoimeksi jättämistä" muiden täydennettäväksi sekä toisten kutsumista erilaisin elein jatkamaan ajatusta ja keskustelua. Tällainen yhteiseen tiedonmuodostukseen tähtävä vuorovaikutus mahdollisti alustavien, hetkessä mieleen juolahtavien ideoiden esittämisen, mikä oli yhteisölliselle luovalle prosessille keskeistä.

Kolmannessa vaiheessa analysoimme aineistosta ekspansiivisia oppimistekoja, joista seuraavat esiintyivät Muutoslaboratorio-hankkeen kulussa: 1) vallitsevien käytäntöjen kyseenalaistaminen, 2) vallitsevien käytäntöjen analyysi, 3) uuden ratkaisun mallintaminen sekä hankkeen loppuvaiheessa 4) uuden mallin tutkiminen ja koettelu (ks. Engeström 2014). Tutkiessamme ekspansiivisia oppimistekoja ja 


\section{VISION PUUTE HAASTOI \\ KÄYNNISSÄ OLLUTTA}

KOULUN OMAA

OPETUSSUUNNITELMATYÖT $\ddot{\text { Ä. }}$

luovia harppauksia rinnakkain havaitsimme, että luovan harppauksen sysäsi alkuun aina jokin työtoiminnasta tunnistettu ristiriita tai jännite. Harppausten havaittiin lisäksi olevan yhteydessä sellaisiin Muutoslaboratorio-prosessin vaiheisiin, joissa ryhmän vuorovaikutuksen painopiste oli siirtymässä ekspansiivisen oppimissyklin yhdestä vaiheesta seuraavaan.

\section{TULOKSET: YHTEISÖLLINEN LUOVUUS JA EKSPANSIIVINEN OPPIMINEN MUUTOSLABORATORIOSSA}

Valitsimme tarkasteltavaksi vuorovaikutusjaksot kolmannesta ja kuudennesta kokouksesta, sillä kolmas kokous osoittautui hankkeen käännekohdaksi. Siinä ilmeni luovia tekoja ja oppimistekoja, joiden kautta ryhmä otti ensi askeleen kohti uuden pedagogisen tiimityö- ja johtamismallin edellyttämää käsitteenmuodostusta. Kuudennessa kokouksessa hankkeessa kehitellyt ajatukset puolestaan kiteytettiin konkreettiseksi malliksi. Ennen kolmatta kokousta ryhmässä ei ilmennyt jaetun luovuuden piirteitä: vasta tuolloin aloimme havaita luovien tekojen ketjuuntumista ja luovia harppauksia. Puheenvuorojen märä kasvoi merkittävästi kuudennessa kokouksessa (taulukko 1) luovan vuorovaikutuksen ja mallintamisen aikana.

\section{Ensimmäinen vuorovaikutusjakso: työtoiminnan jaetun kohteen yhteistä etsintää}

Muutoslaboratorion kahdessa ensimmäisessä kokouksessa oli keskitytty kyseenalaistamaan ja kritisoimaan koulun joitakin historiallisesti kehittyneitä vallitsevia toimintakäytäntöjä ja "annettuja totuuksia". Tämä voidaan tulkita ensimmäiseksi ekspansiiviseksi oppimisteoksi, kyseenalaistamiseksi. Kolmanteen kokoukseen tultaessa osallistujat olivat päässeet yhteisymmärrykseen siitä, että koululta puuttui yhteinen jaettu visio, joka tukisi opettajia heidän ydintehtäviensä, perusopetuksen, opetusharjoittelijoiden ohjauksen ja tutkimuksen, toteuttamisessa. Koulun toimintajärjestelmän ristiriidaksi koettu vision puute heijastui käynnissä olleeseen koulun omaan opetussuunnitelmatyöhön ja haastoi sen etenemistä.

Seuraavaksi esitettävään vuorovaikutusjaksoon asti osallistujat olivat käsitelleet lähes yksinomaan omaa työtään sekä koulun rakenteita ja johtamista koskevia jännitteitä ja vaikeuksia, eivätkä 'oppilaat' olleet nousseet kertaakaan keskusteluun. Noin 40 minuutin kohdalla kolmatta kokousta tutkijat toivat keskusteluun oppilaan käsitteen johdatellakseen keskustelua kohti tilanteen analysointia, toista ekspansiivista oppimistekoa, sekä ratkaisumallien etsimistä jännitteiden ja haasteiden ylittämiseksi. Seuraavassa katkelmassa tutkijan (TU1) maininta oppilaasta antaa sykäyksen tämän vuorovaikutusjakson ensimmäiseen luovaan tekoon, kun opettaja (VO6) tulee lausuneeksi alustavan ehdotuksen koulun mahdollisesta yhteisestä visiosta.

1215 TU1:--- Ett se on tässä ollu se ajatus, ett kun mainitsitte itse, että olis hyvä olla jokin yhteinen tavote tai yhteinen kohde, että se ois jotenkin enemmän kun se tota metsä [puilta], tai ois tämmöset raamit, [---] että voisko olla sitten joku yhteinen asia, mikä niinku helpottas, tekis joustavammaks, helpommaks sen oppilaiden kanssa toimimisen.

1218 VO6: Jos mä heitän hatusta, niin esimerkiksi sosiaalinen oikeudenmukaisuus tai yhteiskunnan huomioiminen koulunpidossa. Ne on niinku mun mielestä...

1219 VO3: Ne on niinku laajempia käsitteitä kyllä.

1220 VO6: Voi olla, että oon väärässä --- mutt ne on mun mielestä sen tyyppisii...

1221 TU1: Joo.

1222 VO6: yhteisii tavotteita.

1223 VO3: Kyllä, kyllä, joo! 
Vaikka lausahdus ei ollut tarkoitettu varsinaiseksi ehdotukseksi yhteisestä visiosta, tutkijat ja muut osallistujat alkoivat käsitellä sitä sellaisena. Näin ilmaisu sai uusia merkityksiä vuorovaikutuksen edetessä.

1264 VO6: Huomaatte, ett mä en ehdottanu sitä yhteiseks kohteeks, vaan mä annoin esimerkin vaan sen tyyppisestä abstraktiotasosta, mikä voisi olla.

Jakson toinen luova teko ilmeni, kun toinen opettaja (VO9) ehdotti uuden opetussuunnitelman tavoitteita mahdolliseksi yhteiseksi visioksi. Osallistujat kuitenkin havaitsivat pian, etteivät opetussuunnitelman sisällöt sellaisenaan sopineet vastauksiksi koulun senhetkisiin muutostarpeisiin.

1292 VO9: Nouseeks meill sielt uudesta opetussuunnitelmasta jotain semmosia ---

1293 VO6: No siell on ne, laaja-alaiset osaamisen alueethan siell on, niit on seittemän.

1294 VO9: Nii. Ett onks joku sitt niistä semmonen?

1295 VO6: Ei niistä yhtä voi nostaa. Eli näit täytyy joka tapauksessa tavotella, kun ne on kerran siellä opetussuunnitelmassa.

1296 VO2: Ne on normeja.

Lyhyen, uutta opetussuunnitelmaa koskeneen keskustelun jälkeen opettaja (VO3) teki vuorovaikutusjakson kolmannen luovan teon tuomalla keskusteluun ajatuksen lasten tulevaisuudesta. Hän kertasi aiemmin esitetyt käsitteet - oppilaan, yhteiskunnan ja opetussuunnitelman - ja kokosi ne yhteen ehdotukseksi jaetusta toiminnan kohteesta.

1313 VO3: Mietin tota, ku [VO6] sano ton ympäröivän ihmisen yhteiskunnan huomioiminen, ni eiks ne kuitenkin ne kaikki laaja-alaisen osaamisen tavotteet liity siihen, että miten se lapsi sitten pärjää, tulee selviämään, minkälaisia valmiuksia se saa toimiakseen siellä tulevaisuuden yhteiskunnassa?

1314 VO6: Joo, koska ne on niitä laaja-alaisen osaamisen osa-alueita

1315 VO3: \#\# Nii, nii.
1316 VO6: Ne oppiaineet tukeutuu niitten kehittymiseen.

1317 VO3: \#\# Nii, nii, nii. - Eli voisko siitä saada jonku sellasen yhteisen?

1318 TU2: Miten se lapsi pärjää.

1319 VO3: Nii.

1320 TU1: Minkälaisia valmiuksia lapsi saa yhteiskunnassa toimimiseen.

1321 VO3: Nii, juuri näin.

Ekspansiivisen oppimisen näkökulmasta ensimmäinen vuorovaikutusjakso muodostaa laadullisen, ekspansiivisen siirtymän muutostarpeen tiedostamisesta jaetun toiminnan kohteen käsitteellistämiseen (Engeström 2008). Jakso on samalla tärkeä taitekohta siirryttäessä vallitsevien työkäytäntöjen kyseenalaistamisesta kohti toista ekspansiivista oppimistekoa, vallitsevien työkäytäntöjen analysointia (ks. Engeström 2014)

Edellä olevissa katkelmissa kuvataan kolmen peräkkäisen luovan teon ketjuuntuminen, jossa voidaan havaita useita jaetun luovuuden piirteitä: yksittäisen teon vuorovaikutuksellisen merkityksen muuttumista seuraavien tekojen myötä, sattumanvaraisuutta, tekojen keskinäistä riippuvuutta, merkitysten kasautumista sekä yhteistoimintaa, jossa eri toimijoiden tuotoksilla on tasavertainen rooli ( $\mathrm{ks}$. Sawyer \& deZutter 2009). Vuorovaikutuksen seurauksena muodostui luova harppaus, kun luovan prosessin odottamaton tulos, alustava ehdotus kouluyhteisön toimintaa ohjaavaksi visioksi, tuotti alustavan ratkaisumallin aiemmin tunnistettuun toimintajärjestelmän ristiriitaan.

\section{Toinen vuorovaikutusjakso: pedagogisen yhteistyön dynaamisen tiimimallin visiointia}

Neljäs Muutoslaboratorio-kokous painottui harjoittelukoulun historiallisen kehityksen yhteiseen analysointiin ja nykyisen toiminnan keskeisten, koulun historiasta periytyvien jännitteiden tunnistamiseen. Viidennessä kokouksessa keskityttiin ideoimaan mahdollisia uudenlaisia tiimirakenteita ja pohtimaan tiimien roolia koulun pedagogisen toiminnan johtamisessa, enteillen alla 


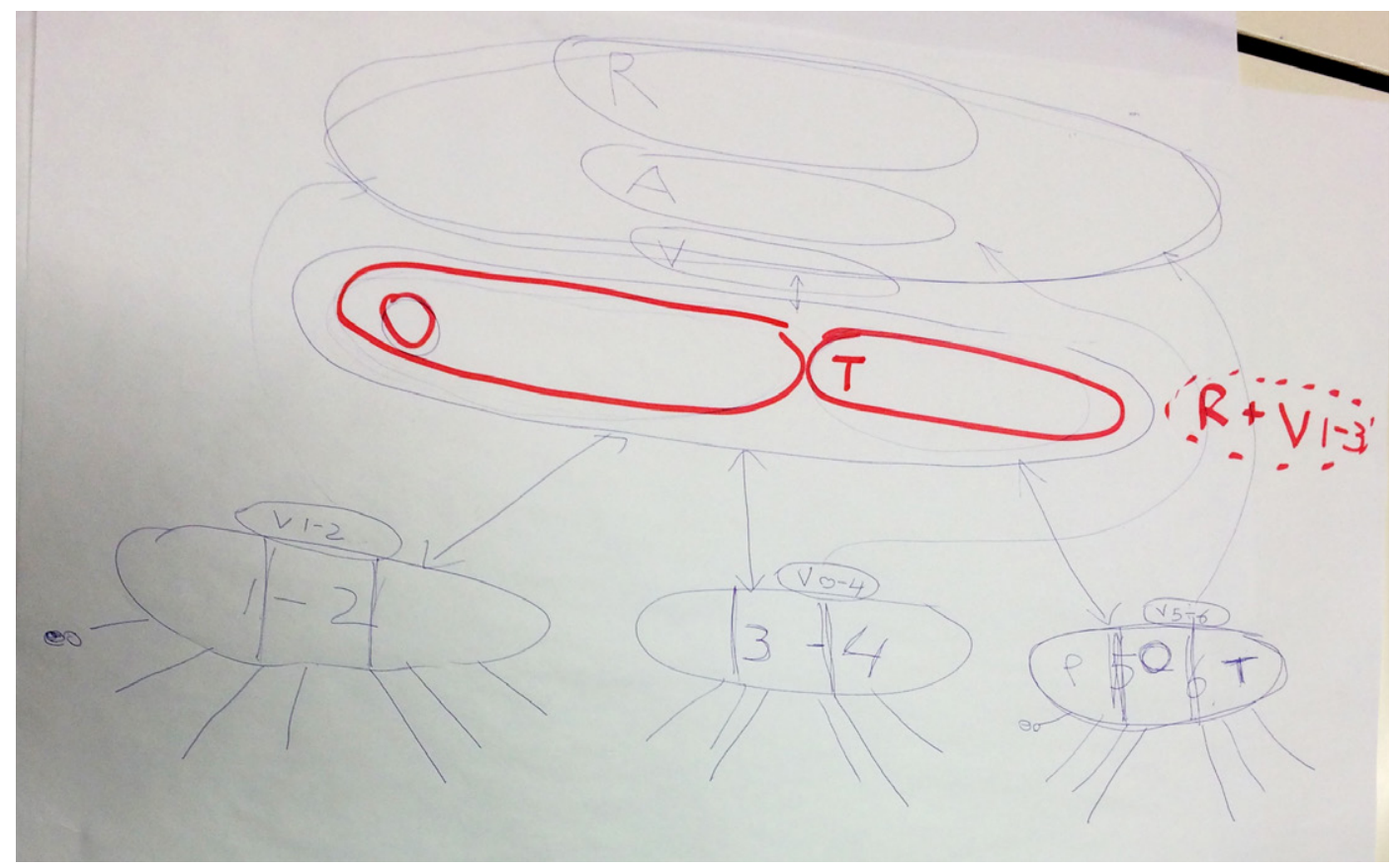

Kuva 1. Tiimityö- ja johtamismallin ensimmäinen versio.

kuvattua kuudennessa kokouksessa tapahtuvaa uuden ratkaisun mallintamista, kolmatta oppimistekoa.

Kuudennen kokouksen jälkipuoliskolla osallistujat olivat päässeet yhteisymmärrykseen siitä, että koulun opetussuunnitelmatyön ja pedagogisen yhteistyön parantaminen edellyttäisi luokka-asteiden mukaan jaettujen opettajatiimien perustamista. Koulun muiden päätehtävien eli "funktioiden" - ohjauksen ja tutkimuksen ja opetuksen kehittämisen - kannalta tällainen tiimijako koettiin kuitenkin ongelmalliseksi. Ristiriidasta huolimatta osallistujat ottivat mallinnuksensa lähtökohdaksi jaon luokka-asteiden mukaan. Tämän vuorovaikutusjakson ensimmäisenä luovana tekona opettaja (VO5), muiden avustamana, piirsi yhdessä kehiteltyjen ajatusten pohjalta ensimmäisen luonnoksen tiimipohjaisesta pedagogisen johtamisen mallista (kuva 1).

Mallin ensimmäinen luonnos herätti kriittistä keskustelua, sillä joidenkin osallistujien mielestä se muistutti liiaksi perinteistä hierarkkista organisaatiomallia, eikä tukisi kaivattua toiminnan muutosta. Tämä keskustelu johti jakson toiseen luovaan tekoon, kun uusi opettaja (UO1) esitti mallin piirtämistä uudelleen "rinkulan" muotoon.
3537 UO1: Mä mietin myös, että onks se... että tää on nyt tällanen niinku hierarkinen malli, joka siis on...

3538 VO6: \# Se on armeijamalli.

3539 UO1: Ei oo looginen, mikä menee niinku päähän.

3540 VO5: Mutt eiks me... onks me tällasta puhuttu? Onko me puhuttu tästä?

3541 UO1: \#\# Mutta tota voisko se olla niinku joku rinkula?

3542 VO3: Must me ollaan puhuttu tollasesta ---

3543 VO5: \#\# Nii, koska mä niinku ajattelen, ett meiän on hyvä pu...

3544 VO3: \# Mun jäi päähän niinku tommonen viimeiks.

3545 VO5: Nii.

3546 VO3: Mutt että nythän me voidaan ottaa joku ihan... 
3547 VO5: Nii.

3548 VO6: Piirräpä rinkula, tehdää näin! [ojentaa paperia UO1:lle]

Kuudennen kokouksen edetessä alustavaa rinkulametaforaa laajennettiin uusilla määreillä, kuten aurinko, tikkataulu, maalitaulu ja donitsi. Keskustelua uuden tiimityö- ja johtamismallin mahdollisista eri versioista sävytti runsas päällekkäin puhuminen ja nauru, mikä oli merkki luovan yhteistyön kannalta suotuisan ilmapiirin muodostumisesta ja yhteisen merkityksen rakentamisesta (ks. myös Engeström ym. 2015).

Jakson kolmantena luovana tekona opettaja (VO6) ehdotti, että luokkatasotiimit ja tietyn funktion, toisin sanoen ohjauksen, tutkimuksen tai opetuksen kehittämisen, mukaan jaetut tiimit esitettäisiin mallissa rinnakkain. Idean taustalla vaikutti rinkulametaforan myötä vuorovaikutuksen välittäjäksi muodostunut ajatus mallin kehämäisestä muodosta.

3564 VO6: Nii, jos täällä kehällä onkin noita [tiimejä], ett osa on noita ikätason, mutt sitten ois myös funktionaalisia. Toi donitsi onki niinku tällanen. [alkaa piirtää uutta kuvaa]

Opettaja (VO6) piirsi uuden kehämäisen mallin (kuva 2) luokkatasotiimeineen (1-2, 3-4 ja 5-6) ja funktiokohtaisine tiimeineen (opetus, ohjaus ja tutkoke). Myöhemmin funkiokohtaisten tiimien vaihtoehdoksi esitettiin luokkakirjaimen (A, B ja C) tai koulurakennuksen kerrosten mukaista tiimijakoa.

Donitsimallin piirtämistä seurasi nopeatempoinen tiimijaon ideointi, jonka perusajatus päätyikin myöhemmin mallin lopulliseen versioon. Seuraavassa katkelmassa opettaja (UO1) teki opettajan (VO6) ajatukseen perustuen jakson neljännen luovan teon ehdottaessaan, että opettajat voisivat työskennellä joustavasti joko luokkatasotiimeissä tai funktiokohtaisissa tiimeissä.

3575 UO1: [---] että sitten onkin niinku tutkoke-ryhmä, ohjausryhmä ja opetusryhmä.

3576 VO6: Nii, nämä kolme.
3577 UO1: Eli että meill oliski itse asiassa kuus tiimiä. Me toimitaan joko näin tai noin [osoittaa eri suuntiin "donitsin" yli].

3578 VO6: \#\# No niin!

Ekspansiivisen oppimisen kannalta toinen vuorovaikutusjakso kuvaa ryhmän edestakaista liikettä kahden ekspansiivisen oppimisteon, vallitsevan käytännön analysoinnin ja uuden ratkaisun mallintamisen, välillä (ks. Engeström 2014). Ensimmäisen vuorovaikutusjakson tavoin toisen jakson vuorovaikutuksessa ilmeni useita jaetun luovuuden piirteitä. Jakson neljä peräkkäistä, toisiinsa kytkeytyvää luovaa tekoa muodostivat luovan harppauksen, joka edisti ekspansiivista oppimista muodostamalla aihion uudenlaiseksi dynaamisen pedagogisen tiimityön käytännöksi, joka konkretisoitui kehämäisessä "donitsimallissa" (kuva 2). Malli tarjosi ratkaisun opetussuunnitelmatyön ja kehitystyön, eli ohjauksen, tutkimuksen ja opetuksen kehittämisen, edellyttämien eriävien yhteistyökäytäntöjen ristiriitaan ja toimi lähtökohtana seuraavassa jaksossa kuvatulle luovalle vuorovaikutukselle.

\section{Kolmas vuorovaikutusjakso: dynaamisen pedagogisen johtamismallin keksiminen}

Muutoslaboratorio-prosessin alkuvaiheen keskustelussa oli yhtenä keskeisenä ristiriitana noussut esiin toimivien pedagogisen johtamisen ja päätöksenteon rakenteiden puuttuminen koulusta. Ensimmäisen tunnin kohdalla kuudennessa kokouksessa ryhmä keskustelikin dynaamisten tiimien roolista koulun pedagogisessa päätöksenteossa, kun uusi opettaja (UO1) ryhtyi piirtämään keskustelun pohjalta uutta mallia. Pidimme piirtämisen aloittamista kolmannen esittelemämme vuorovaikutusjakson ensimmäisenä luovana tekona.

3820 UO1: Siis se, että jos täällä nyt on sitt kaikki nää rehtorit täällä keskellä, jos haluttii niitten ympärillä olla, ni sitt täss olis nää tiiminvetäjät nää kolme, nämä.

3821 VO5: Nii, oisko se johtoryhmän nimellä, vai millä nimellä me kutsuttais?

3822 VO3: \#\# Joo, johtoryhmä. 
LUOVA HARPPAUS

TUNNISTETTIIN TYYPILLISESTI

LUOVIEN TEKOJEN

MERKITYSTEN MUUTTUMISESTA

JA KESKIN ̈̈ISEST $\ddot{A}$

RIIPPUVUUDESTA SEK $\ddot{A}$

PROSESSIN

SATTUMANVARAISUUDESTA.

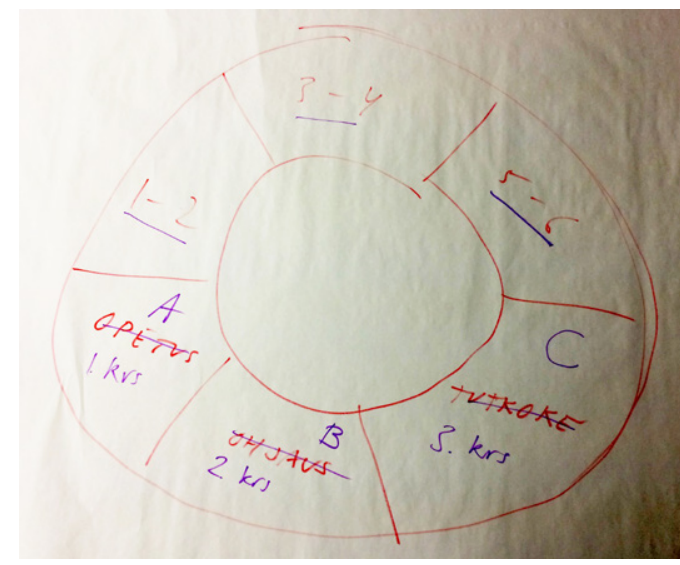

Kuva 2. Opettajan ST6 aloitteesta syntynyt "donitsimalli".

Tässä kohdin ideointi oli luonteeltaan vapautunutta ja johti jakson toiseen luovaan tekoon. Siinä opettaja (VO5) alkoi piirtää vaihtoehtoista mallia, jossa oli lukuisia sisäkkäisiä kehiä, mutta tiimien luokkakirjanjako oli hylätty. Opettaja (UO1) liittyi pian tähän luovaan prosessiin (kuva 3).

3844 VO5: Mä luulin, ett sä rupeet piirtää niinku tämmöstä, ett tääll on niinku se niinku tää johtoryhmä ja rehtori, tai rehtori ja johtoryhmä, ja sitte tässä on niinku ne tiiminvetäjät. [piirtää pienen ympyrän ja sen ympärille toisen ympyrän]

3845 UO1: Joo.

3846 VO3: Mäki luulin. Sitt seuraava askel ---

3847 VO5: \#\# Mä luulin, ett täst tulee tämmönen malli, ett tää rupee kasvamaan. [piirtää lisää ympyröitä]

3848 UO1: \#\# Voihan tähän laittaa! Voihan tähän laittaa ne opettajat näin.

Tutkijat eivät osallistuneet mallien piirtämiseen missään vaiheessa Muutoslaboratoriota. Kolmannessa vuorovaikutusjaksossa tutkija (TU1) teki kuitenkin jakson kolmannen luovan teon ehdottamalla rinnakkaisiin malleihin (kuva 3) muotoiltujen ideoiden yhdistämistä: kerroksittain ulos avautuvan kehämallin ajatuksen voisi yhdistää opettaja UO1:n aiempaan ajatukseen tiimin "pyörimisestä" kehällä 


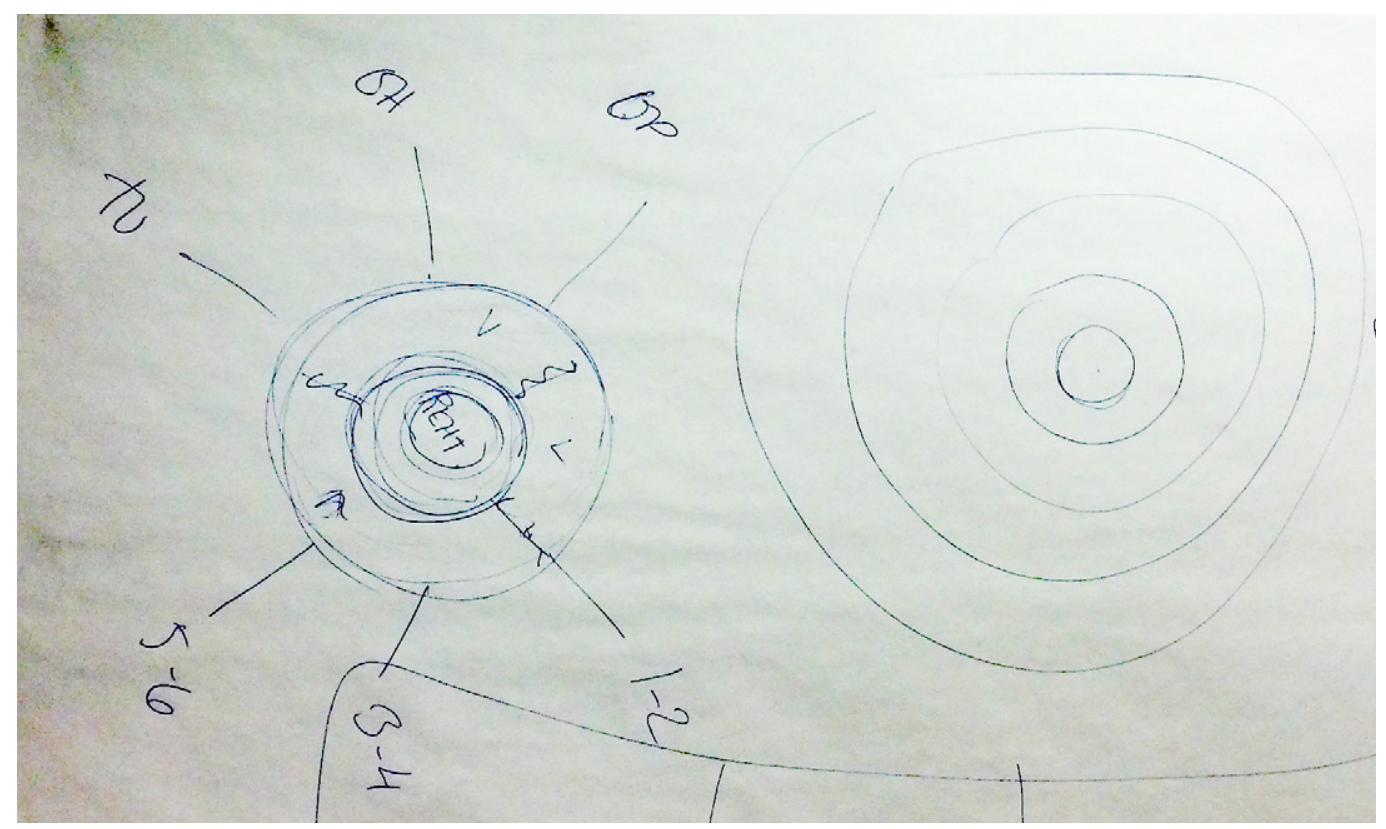

Kuva 3. Mallin seuraavat versiot, piirtäjinä UO1 (vasemmalla) ja VO5 (oikealla).

joustavasti kulloisenkin tehtävän mukaan, kuvastaen toiminnan suuntaa osoittavaa kompassin neulaa.

3850 TU1: Onks toi vähän niinku semmonen pedagoginen kompassi nyt sitte, että se on niinku dynaaminen. Ett se ei ookkaan malli näin [viittoo ylhäältä alas], vaan se liikkuu näin [viittoo pyörivää liikettä].

\section{VO5: Nii, sitte me...}

3852 TU1: Eiks se oo vähän mitä [VO6] hait tossa.

\section{VO5: Nii, joo.}

3854 VO6: Kompassimalli, se on kompassimalli.

Ekspansiivisen oppimisen kannalta kolmas vuorovaikutusjakso edustaa kolmatta oppimistekoa, uuden ratkaisun mallintamista, sekä ensi askeleita kohti neljättä oppimistekoa, uuden ratkaisun tutkimista ja koettelua (ks. Engeström 2014). Ensimmäisen ja toisen vuorovaikutusjakson tavoin kolmannessa vuorovaikutusjaksossa nähdään luovien tekojen jatkumo, jossa on havaittavissa monia jaetun luovuuden piirteitä. Jaksossa kuvattu yhteistoiminnallinen malliversioiden piirtäminen muodosti Muutoslaboratorion viimeisen luovan harppauksen, jossa kehitettiin uuden tiimityö- ja johtamismallin keskeiset toimintaperiaatteet. Kuudennen kokouksen päätteeksi viimeistellyn "kompassimallin” nähtiin muodostavan toimivan pohjan kouluyhteisön pedagogisen yhteistoiminnan ja johtamisen käytäntöjen uudistamiseksi.

\section{POHDINTA}

Tutkimuksemme tuottaa uutta tietoa yhteisöllisen luovuuden ja ekspansiivisen oppimisen yhteydestä harjoittelukoulun opettajayhteisön kehittämishankkeen kontekstissa. Lähestyimme luovuutta yhteisöllisenä prosessina ja tarkastelimme moniäänistä asiantuntijoiden ryhmää, joka muodostui eri taustoista tulevista opettajista sekä rehtorista. Yksilökeskeisestä luovuustutkimuksesta (ks. esim. Amabile 1996; Woodman ym. 1993; Sternberg \& Lubart 1999) 
poiketen huomiomme kohdistui ryhmän yhteisöllisen luovuuden ja ekspansiivisen oppimisen tutkimiseen.

Tutkimustuloksemme osoittavat uusien käsitteiden ja toimintamallin syntyneen yhteisöllisen luovan vuorovaikutusprosessin kautta. Analyysissämme nousi esiin useita luovien tekojen jatkumoita. Vuorovaikutuksessa ne ketjuuntuivat uudenlaisiksi jaetuiksi käsitteellistyksiksi, joita kutsuimme luoviksi harppauksiksi. Ne puolestaan olivat merkityksellisiä ryhmän ekspansiiviselle oppimiselle muodostamalla uudenlaisia, luovia ratkaisumalleja ekspansiivisen oppimisen prosessissa esiin nousseisiin työtoiminnan ristiriitoihin. Muutoslaboratorion lopuksi monet kehitellyistä ratkaisuista koottiin uudeksi pedagogisen tiimityön ja johtamisen malliksi, joka sisälsi mullistaviakin uudistuksia työyhteisön toimintatapoihin.

Luovan prosessin käännekohta koettiin kolmannessa kokouksessa, kun ryhmä saavutti yhteisymmärryksen koulun laajemmasta visiosta. Keskeistä ei ollut niinkään, oliko juuri tuo ensimmäisessä kuvaamassamme vuorovaikutusjaksossa kehitelty visio paras mahdollinen koulun tarpeisiin vaan se, että näin muodostui jaettu toiminnan kohde, joka aiemmin ilmaistuihin muutostarpeisiin peilattuna antoi toiminnalle yhteisen merkityksen ja suunnan (ks. myös Engeström 2008). Jaetun kohteen myötä ryhmän oli mahdollista siirtyä jännitteiden ja haasteiden tarkastelusta kohti uusien pedagogisen yhteistyön mallien hahmottamista. Ensimmäistä vuorovaikutusjaksoa voikin pitää ponnahduslautana ekspansiiviselle mallinnusprosessille, jonka myötä uusia käytäntöjä ryhdyttiin yhteistoiminnallisesti muodostamaan. Tuloslukumme toinen ja kolmas vuorovaikutusjakso kuvaavat yhteisöllisen luovuuden ja ekspansiivisen oppimisprosessin etenemistä ryhmän muodostaessa yhteistoiminnallisesti aivan uudenlaisia tiimityön ja johtamisen käsitteitä ja toimintatapoja.

Tutkimustuloksemme osoittavat, että yhteisöllinen luovuus voidaan mieltää yhteisen toiminnan kohteeseen suuntautuneeksi vuorovaikutusprosessiksi, joka sisältää jännitteitä, tiedon jakamista sekä uusien käsitteiden ja yhteisten toimintamallien muodostumista. Muutoslaboratoriossa uusien käsitteiden muodostus tukee toiminnan ristiriitojen yhteis- toiminnallista ratkaisemista. Tuloksemme viittaavat siihen, että osallistavissa kehittämismenetelmissä on erityisen tärkeää kiinnittää huomiota osallistujien luovuuteen. Tutkimuksemme menetelmällinen uutuusarvo on kehittämässämme luovien tekojen ja niiden ketjuuntumisena syntyvien luovien harppausten analyysimenetelmässä.

Tulokset herättävät teoreettisia ja menetelmällisiä kysymyksiä, joihin on syytä paneutua tulevaisuudessa. Esittelemämme uusi käsitteistö onkin ensimmäinen askel kohti toiminnan teoriaan nojaavaa yhteisöllisen luovuuden "kielioppia”, joka voi jatkokehittelyn myötä auttaa yhä paremmin ymmärtämään yksittäisten luovien tekojen nivoutumista yhteisöllisessä, luovassa vuorovaikutuksessa laajemmaksi toiminnaksi ja ekspansiiviseksi oppimiseksi.

Tutkimustuloksemme voivat hyödyttää esimerkiksi koulutusorganisaatioiden muutosprosessien suunnittelua, joissa on tarve sisäisesti kehittää pedagogisen yhteistyön ja johtamisen malleja. Tutkimuksemme ei kuitenkaan anna tietoa toiminnan teoreettisen kehittämishankkeen pitkän aikavälin seurauksista, mitä on edelleen tutkittu melko vähän (ks. Kajamaa 2011). Kiinnostava jatkotutkimuskohde onkin Muutoslaboratorioissa ja muissa osallistavissa oppimisympäristöissä tapahtuvien yhteisöllisten luovien prosessien pitkän aikavälin vaikutus yhteisön muutostoimijuuden tai työpaikkakulttuurin kehittymiseen.

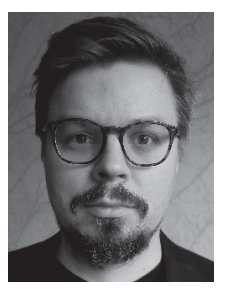

\section{SAKARI HYRKKÖ}

FM, tohtorikoulutettava kasvatustieteellinen tiedekunta Helsingin yliopisto

(iD https://orcid.org/0000-00025951-2671

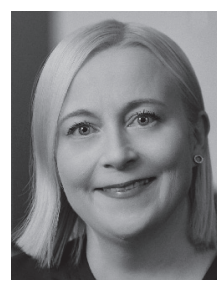

ANU KAJAMAA

$\mathrm{FT}$, professori kasvatustieteiden tiedekunta Oulun yliopisto

(iD https://orcid.org/0000-00026397-545X 
Amabile, T. M. (1996). Creativity in Context. 2. painos. Boulder, Co: Westview Press.

Anderson, N., Potočnik, K. \& Zhou, J. (2014). Innovation and creativity in organizations: A state-of-the-science review, prospective commentary, and guiding framework. Journal of Management, 40(5), 1-37.

Córdova, R., Kumpulainen, K. \& Hudson, J. (2012). Nurturing creativity and professional learning for $21 \mathrm{st}$ century education: Responsive Design and the Cultural Landscapes Collaboratory. Learning Landscapes, 6(1), 157-180.

Csikszentmihalyi, M. (1996). Creativity: Flow and the psychology of discovery and invention. New York: Harper Collins.

Drazin, R., Glynn, M. \& Kazanjian, R. (1999). Multilevel Theorizing about Creativity in Organizations: A Sensemaking Perspective. The Academy of Management Review, 24(2), 286-307.

Engeström, Y. (2008). From Teams to Knots: Activity-theoretical studies of collaboration and learning at work. Cambridge: Cambridge University Press.

Engeström, Y. (2011). From design experiments to formative interventions. Theory \& Psychology, 21(5), 598-628.

Engeström, Y. (2014). Learning by expanding: An activity-theoretical approach to developmental research. Cambridge: Cambridge University Press.

Engeström, Y., Engeström, R., \& Kärkkäinen, M. (1995). Oppiminen ja ongelmaratkaisu monimutkaisissa työprosesseissa: monikontekstisuus ja rajanylitykset asiantuntijakognitiossa. Aikuiskasvatus, 15(1), 14-27. https://doi.org/10.33336/aik.92303

Engeström, Y., Virkkunen, J., Helle, M., Pihlaja, J. \& Poikela, R. (1996). The Change laboratory as a tool for transforming work. Lifelong Learning in Europe 1(2), 10-17.

Engeström, Y., Kerosuo, H. \& Kajamaa, A. (2007). Beyond discontinuity: expansive organizational learning remembered. Management Learning, 38(3), 319-336.

Engeström, Y., Kajamaa, A., Kerosuo, H. \& Laurila, P. (2010). Process enhancement versus community building: Transcending the dichotomy through expansive learning. Teoksessa K. Yamazumi (toim.), Activity theory and fostering learning: Developmental interventions in education and work, 1-28. Osaka: Kansai University Press.

Engeström Y. \& Sannino, A. (2010). Studies of expansive learning: Foundations, findings and future challenges. Educational Research Review, 5(1), 1-24.
Engeström Y., Rantavuori, J \& Kerosuo, H. (2013). Expansive Learning in a Library: Actions, Cycles and Deviations from Instructional Intentions. Vocations and Learning, 6(1), 81-106.

Engeström, Y., Sannino, A. \& Virkkunen, J. (2014). On the Methodological Demands of Formative Interventions: [Commentary]. Mind, Culture, and Activity, 21(2), 118-128.

Engeström, Y., Kajamaa, A., Lahtinen, P. \& Sannino, A. (2015). Toward a grammar of collaboration. Mind, Culture and Activity 22(2), 92-111.

Glaveanu, V. P. (2011). How are we creative together? Comparing sociocognitive and sociocultural answers. Theory \& Psychology, 21(4). 473-492.

Glaveanu, V. P. (2015). Creativity as a sociocultural act. The Journal of Creative Behavior, 49(3), 165-180.

Greeno, J. (2006). Learning in Activity. Teoksessa R. Sawyer (toim.), The Cambridge Handbook of the Learning Sciences, 79-96. Cambridge: Cambridge University Press.

Gruys, M. L., Munshi, N. \& Dewett, T. C. (2011). When antecedents diverge: Exploring novelty and value as dimensions of creativity. Thinking Skills and Creativity, 6(2), 123-137.

Hakkarainen, K., Lallimo, J., \& Toikka, S. (2012). Kollektiivinen asiantuntijuus ja jaetut tietokäytännöt. Aikuiskasvatus, 32(4), 246-256. https://doi. org/10.33336/aik.94003

Hakkarainen, K., Hytönen, K., Makkonen, J., SeitamaaHakkarainen, P. \& White, H. (2013). Interagency, collective creativity, and academic knowledge practices. Teoksessa A. Sannino \& V. Ellis (toim.), Learning and Collective Creativity: Activity-theoretical and sociocultural studies, 77-99. New York: Routledge.

John-Steiner, V. (2000). Creative collaboration. Oxford: Oxford University Press.

Kajamaa, A. (2011). Unraveling the helix of change: an activity-theoretical study of health care change efforts and their consequences. Helsinki: Unigrafia.

Kajamaa, A., Kumpulainen, K. \& Olkinuora, H-R. (2019). Teacher interventions in students' collaborative work in a technology-rich educational makerspace. British Journal of Educational Technology, 51(2), 371-386.

Kajamaa, A. \& Kumpulainen, K. (2020). Students' Multimodal Knowledge Practices in a Makerspace Learning Environment. International Journal of Computer-Supported Collaborative Learning, 15(4), 411-444.

Kaufman, J. C. \& Sternberg, R. J. (toim.) (2009). The Cambridge handbook of creativity. Cambridge: Cambridge University Press. 
Kerosuo, H., Kajamaa, A. \& Engeström, Y. (2010). Promoting innovation and learning through Change Laboratory: An example from Finnish Health Care. Central European Journal of Public Policy, 4(1), 110-131.

Littleton, K., Taylor, S., Eteläpelto, A. (2012). Special issue introduction: Creativity and creative work in contemporary working contexts. Vocations and Learning, 5(1), 1-4.

McCharen, B, Song, J. \& Martens, J. (2011). School Innovation: The Mutual Impacts of Organizational Learning and Creativity. Educational Management Administration \& Leadership, 39(6), 676-694.

Miettinen, R. (2013). Creative Encounters, Collaborative Agency, and the Extraordinary Act of the Meeting of a Need and an Object. Teoksessa A. Sannino \& V. Ellis (toim.), Learning and Collective Creativity: Activitytheoretical and sociocultural studies, 158-176. New York: Routledge.

Oddane, T. (2014). The collective creativity of academics and practitioners in innovation projects. International Journal of Managing Projects in Business, 8(1), 33-57.

Riikonen, S., Seitamaa-Hakkarainen, P. \& Hakkarainen, K. (2020). Bringing maker practices to school: tracing discursive and materially mediated aspects of student teams' collaborative making processes. International Journal of Computer-Supported Collaborative Learning, 15(3), 319-349.

Runco, M. \& Beghetto, R. (2019). Primary and secondary creativity. Current Opinion in Behavioral Sciences, 27, 7-10.

Sannino, A. \& Ellis, V. (toim.) (2013). Learning and Collective Creativity: Activity-Theoretical and Sociocultural Studies. New York: Routledge.
Sawyer, R. K. (2004). Creative Teaching: Collaborative Discussion as Disciplined Improvisation. Educational Researcher, 33(2), 12-20.

Sawyer, R. K. \& deZutter, S. (2009). Distributed Creativity: How Collective Creations Emerge from Collaboration. Psychology of Aesthetics, Creativity, and the Arts, 3(2), 81-92.

Schulz, K. P., Kawamura, T. \& Geithner, S. (2017). Enabling sustainable development in healthcare through art-based mediation. Journal of Cleaner Production, 140(3), 1914-1925.

Segers, M., Messmann, G. \& Dochy, F. (2018). Emergence, theoretical foundation, and conceptualization of informal learning at work. Teoksessa G. Messmann, M. Segers \& F. Dochy (toim.), Informal learning at work. Triggers, Antecedents, and consequences, 1-11. New York: Routledge.

Sternberg, R. J. \& Lubart, T. I. (1999). The concept of creativity: Prospects and paradigms. Teoksessa R. Sternberg (toim.), Handbook of creativity, 5-15. Cambridge: Cambridge University Press.

Virkkunen, J., \& Newnham, D. (2013). The Change Laboratory. A tool for collaborative development of work activities. Rotterdam: Sense publishers.

Vygotsky, L. S. (1978). Mind in society: the development of higher psychological processes. Cambridge: Harvard University Press.

Woodman, R. W., Sawyer, J. E. \& Griffin, R. W. (1993). Toward a theory of organizational creativity. Academy of Management Review, 18(2), 293-321. 